\title{
Contaminant-induced lysosomal membrane damage in blood cells of mussels Mytilus galloprovincialis from the Venice Lagoon: an in vitro study
}

\author{
David M. Lowe ${ }^{1, *}$, Valentino U. Fossato ${ }^{2}$, Michael H. Depledge ${ }^{3}$ \\ ${ }^{1}$ Plymouth Marine Laboratory, Citadel Hill, Plymouth PL1 2PB, United Kingdom \\ ${ }^{2}$ Istituto di Biologia del Mare CNR, Castello 1364/A, I-30122 Venice, Italy \\ ${ }^{3}$ Environmental Research Centre, University of Plymouth, Drake Circus, Plymouth PL4 8AA, United Kingdom
}

\begin{abstract}
Damage to blood cell lysosomes was investigated in vitro in mussels Mytilus galloprovincialis collected from a series of sites in the Lagoon of Venice, Italy, and correlated with total tissue burdens for a range of contaminants. Retention of the cationic probe neutral red within the lysosomal compartment over time was used as a measure of damage to the lysosomal membrane. Multi-stepwise regression analysis was used to explore the relationship between altered cellular physiology and total body burdens of contaminants. Organochlorines (DDT, HCH and Aroclor 1254), mercury and cobalt were the principle factors involved in evoking pathological responses.
\end{abstract}

KEY WORDS: Mytilus galloprovincialis - Lysosomes - Blood cells · Pathology · Neutral red retention . Contaminants · Venice Lagoon

\section{INTRODUCTION}

In determining the toxicity of chemicals to marine organisms, it is important to consider a myriad of abiotic factors that affect bioavailability and uptake; for example, salinity, temperature and redox potential, as well as the size, polarity and surface charge of the molecules. Biotic factors are equally important in determining body burdens and toxicity which vary with the organisms' size and age, nutritional state, routes of chemical uptake and capacity to excrete and detoxify chemicals.

From the view of the ecotoxicologist, the problem of predicting adverse effects is made even more difficult in that chemical contaminants seldom occur in isolation in the environment, but are present in a 'cocktail'. Consequently, cause and effect relationships are usually extremely difficult to establish. A notable excep-

•E-mail: d.lowe@pml.ac.uk tion to this generalisation is tributyltin, where it has been possible to relate a particular contaminant to specific biological effects with a reasonably well-defined exposure-response relationship (Bryan et al. 1988). Despite the limitations there is a considerable body of evidence demonstrating that exposure to some chemicals (e.g. trace metals, polyaromatic hydrocarbons and polychlorinated biphenyls), either singly or in combination, is detrimental to animal health.

An understanding of the mechanisms by which chemicals exert their toxicity is a prerequisite to establishing causality. It may then be possible to predict how the presence of other chemicals and changes in abiotic and biotic factors modulate toxicity. One way to achieve this is through the development of sensitive biomarkers that respond to chemical challenges and which can be used to explore the mechanisms involved in contaminant-induced alterations in cell structure and function

Alterations in blood cell functions as a biomarker of contaminant impact and effect have tended to address 
changes in immunological parameters (see review by Weeks et al. 1992). Whilst the potential of immune parameters as determinants of environmental contaminant impact has been acknowledged for many years, there was a paucity of published work on the subject until recently. The principle cellular responses to receive attention have been alterations in phagocytic potential and changes in the size and abundance of melanomacrophage centres of the liver, kidney and spleen of fish. The latter have given rise to some highly variable results (Haensly et al. 1982, Kranz \& Peters 1984). However, in a departure from the more traditional measures of the immunocompetence, recent work by Pipe (1993) and Coles et al. (1994) has addressed alterations in molluscan blood cells that give insight into the mechanisms of the immune response. In their role as components of the immune response, blood cell lysosomes release acid hydrolases which are able to degrade circulating pathogens. However, unscheduled release of acid hydrolases may have disastrous consequences. Once the functional integrity of the lysosomal membrane has been compromised and the acid hydrolases gain free access to the cytoplasm, further damage and disruption to the cell is almost inevitable. Lysosomes have a remarkable ability to accumulate a diverse range of toxic metals and organic chemicals (Moore 1990). However, concentrating contaminants results in enhanced toxicity and cell injury via damage to the lysosomes and leakage of their acid hydrolases as well as the contaminants into the remainder of the cytosol, as described above.

Borenfreund \& Puerner (1985) published a method in which alterations in the capacity of cells to take up the dye neutral red was used as an indicator of cell damage. The rationale used was that healthy cells could take up and retain larger quantities of the dye than damaged cells. The method involved exposing cells to the test medium and then incubating them in a neutral red solution. Following incubation the dye remaining in the cells was extracted and measured spectrophotometrically. For the purpose of these studies and those of Lowe et al. (1992, 1995) and Lowe \& Pipe (1994), it was reasoned that if the dye could be measured with a spectrophotometer it could be visualised through a microscope. Indeed, if the lysosomally accumulated dye could be visualised, then the progress of dye uptake into the cells and, in the case of damaged cells, leakage back into the cytosol could be monitored and quantified using time as the determinant of effect. The retention methods developed by Lowe et al. (1992) for fish hepatocytes and mussel digestive cells (Lowe \& Pipe 1994, Lowe et al. 1995) used microscopy to assess neutral red uptake and efflux, but involved sacrificing the ani- mals and enzymic digestion of tissues, thereby removing the opportunity of follow-on studies to investigate recovery or interactive effects. By contrast, blood cells, which are generally easy to obtain without harming the host, offer a sensitive but robust lysosome rich model cell type that can be studied using in vitro methods and, as an isolated cell, opens the opportunity for further contaminant interaction studies.

The purpose of this investigation was to apply, with some slight modifications, the neutral red retention assay of Lowe \& Pipe (1994) to mussel blood cells in a field study to assess contaminant impact on mussels in the Lagoon of Venice, Italy, and, further, to investigate the relationship between probe retention time and total body burdens for a range of environmental contaminants with a view to exploring causality.

\section{MATERIALS AND METHODS}

For the in vitro studies, 5 mussels Mytilus galloprovincialis (size range 30 to $50 \mathrm{~mm}$ ) were collected during June 1992 and May 1993 from each of a series of sites (see Fig. 1) in the Lagoon of Venice and a reference platform situated approximately $13 \mathrm{~km}$ offshore in the Adriatic Sea. Following transfer to the laboratory, epibionts were removed from the mussel shells. The mussel valves were prised apart with a solid scalpel and $0.5 \mathrm{ml}$ of haemolymph was withdrawn from the anterior adductor muscle into a $2.5 \mathrm{ml}$ hypodermic syringe fitted with a 25 gauge needle and containing $0.5 \mathrm{ml}$ of physiological saline (Peek \& Gabbot 1989). Having obtained the haemolymph sample, the hypodermic needle was discarded to reduce shearing forces during the subsequent expulsion of the syringe contents into a $2 \mathrm{ml}$ siliconised (Sigmacote) Eppendorf tube held in water ice.

Neutral red retention assay. The acid environment of lysosomes is maintained by the membrane $\mathrm{Mg}^{+}$. ATPase dependent $\mathrm{H}^{+}$ion proton pump (Ohkuma et al. 1982); the neutral red retention assay reflects the efflux of the lysosomal contents into the cytosol following damage to the membrane and, possibly, impairment of the $\mathrm{H}^{+}$ion pump (Lowe et al. 1992).

A stock solution of neutral red was made by dissolving $20 \mathrm{mg}$ of dye (C.I. 50040) in $1 \mathrm{ml}$ of DMSO. A working solution was then prepared by diluting $10 \mu \mathrm{l}$ of the stock solution with $5 \mathrm{ml}$ of a mussel physiological saline (Peek \& Gabbot 1989)

A $50 \mu \mathrm{l}$ aliquot of the cell suspension was dispensed onto a $26 \times 76 \mathrm{~mm}$ microscope slide and suspended on a rack in a humidity chamber consisting of a shallow insulated vessel containing water ice (incubation temperature $10^{\circ} \mathrm{C}$ ) for 15 min to allow the cells to attach. 


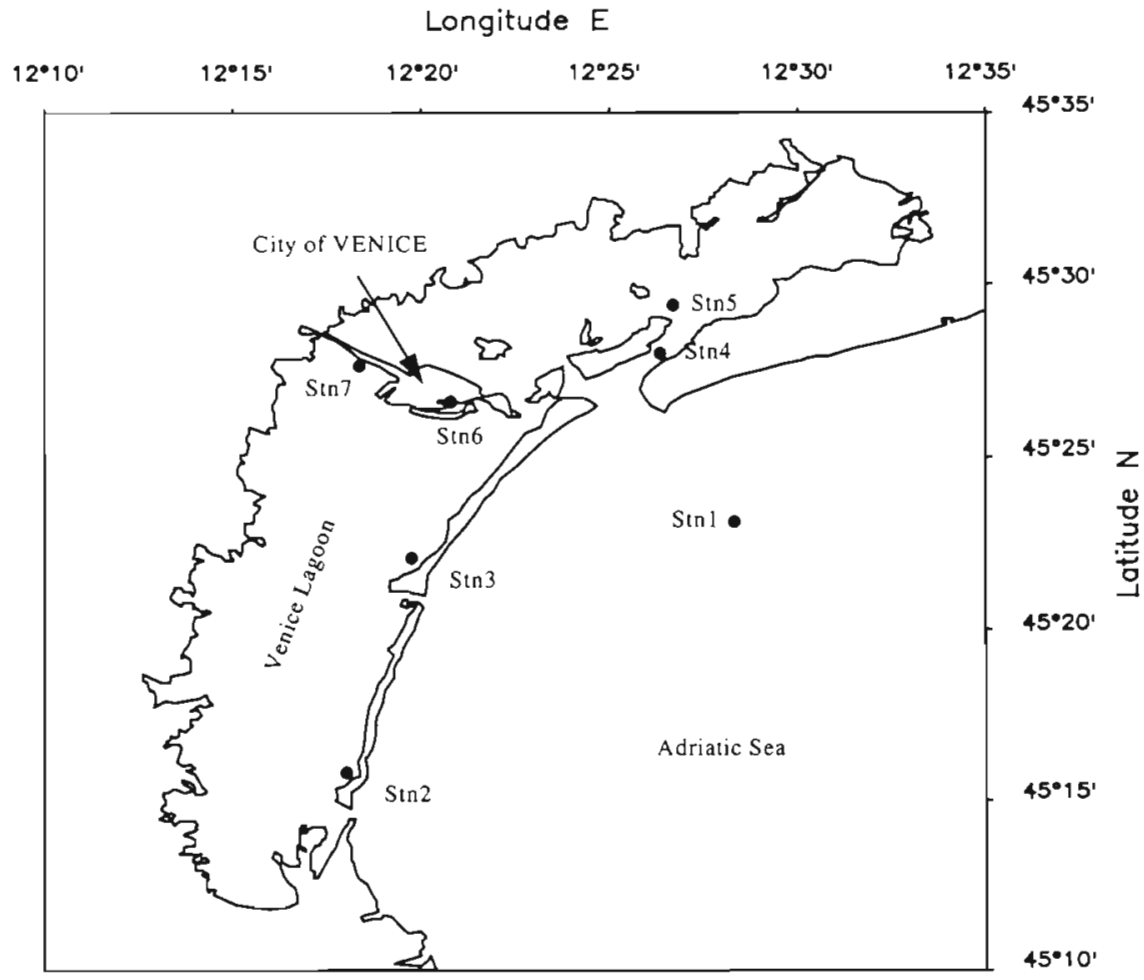

Fig. 1. Sampling sites for mussels in the Adriatic Sea and the Venice Lagoon during 1992 and 1993. Stn 1. Adriatic: platform 8 miles offshore; Stn 2, Chioggia: mussel farm in southern lagoon; Stn 3, Alberoni: mussel farm in central lagoon; Stn 4, Lio Grande: canal in NE lagoon; Stn 5, Crevan: canal in northern lagoon; Stn 6, Salute: inner city site at junction of Grand Canal and Canale della Guidecca (domestic waste inputs); Stn 7, CVE: lagoon site adjacent to industrial area of Porto Marghera (industrial waste inputs)
The excess solution was then carefully tipped off and $40 \mu \mathrm{l}$ of the neutral red working solution added to the area containing the attached cells. A $22 \times 22 \mathrm{~mm}$ coverslip was then applied. After $15 \mathrm{~min}$ incubation in an insulated light proof chamber, the preparations were inspected under a microscope ( $\times 500$ magnification). Following a further 15 min incubation the preparation was examined again and thereafter at 30 min intervals to determine the time at which the dye that had been taken up into individual lysosomes (turning them red) had leached out into the cytosol. The test was terminated when dye loss was evident in $50 \%$ (numerically assessed per field of view) of the small granular haemocytes (Pipe 1990) and the time recorded; the study was truncated at $180 \mathrm{~min}$. Following each inspection, the preparations were returned to the incubation chamber. The procedure as described above does not produce a monoculture, but as the different cell types can be clearly distinguished through the microscope this was not considered to be a problem.

Tissue chemistry (organic contaminants). Composite samples were made up by pooling (depending on flesh weight) the soft parts of between 6 and 10 adult mussels (size range 30 to $50 \mathrm{~mm}$ ) and the tissues blended and freeze dried, recording the wet:dry wt ratio of each sample.

Extraction of hydrocarbons and chlorinated hydrocarbons was accomplished by Soxhlet refluxing approxi- mately $2 \mathrm{~g}$ of freeze dried sample for $8 \mathrm{~h}$ with $\mathrm{n}$-hexane. Extracts were evaporated at $50^{\circ} \mathrm{C}$ to constant weight for determination of extractable organic matter and, after dissolution in $1 \mathrm{ml}$ of $\mathrm{n}$-hexane, fractionated by chromatography on a column of $4 \mathrm{~g}$ of neutral aluminium oxide and $4 \mathrm{~g}$ of silica gel, both deactivated with $5 \%$ water (Reinhardt \& van Vleet 1986). Two portions were eluted: the first with $20 \mathrm{ml}$ of $\mathrm{n}$-hexane contained aliphatic hydrocarbons, PCBs (polychlorinated biphenyls) and pp'DDE (dichloro-diphenyl dichloroethene); the second with $30 \mathrm{ml}$ of hexane-methylene chloride (8:2) contained PAHs (polycyclic aromatic hydrocarbons), $\mathrm{HCH}$ isomers (hexachlorocyclohexane), pp'DDT (dichloro-diphenyl trichloroethane) and its metabolite pp'DDD (dichlorodiphenyl dichloroethane).

Individual column elutriates were analysed using flame ionisation detection and electron capture detection gas chromatography (C. Erba $4160 \mathrm{GC}$ ) using a $30 \mathrm{~m} \times 0.32 \mathrm{~mm}$ i.d. SE-54 fused silica column with hydrogen as a carrier gas. The identity of compounds was deduced from their retention times. Quantification was based on peak area measurements and comparison with responses of reference standards: Kuwait crude oil, alpha $\mathrm{HCH}$, gamma $\mathrm{HCH}$, pp'DDE, pp'DDD, $\mathrm{pp}^{\prime} \mathrm{DDT}, \mathrm{PCB}$ Aroclor 1254 and the $8 \mathrm{PCB}$ congeners (PCB $\sum 8 C$ ) Numbers 52, 101, 110,118+149, 138, 153 and 180 (nomenclature according to Ballschmiter \& Zell 1980). 
PAHs were determined in the second fractions by reverse-phase liquid chromatography (HewlettPackard (HP) 1090A and fluorescence detector, HP 1046A) using $200 \times 2.1 \mathrm{~mm} 5 \mu \mathrm{m}$ Hypersil column (C18) with acetonitrile-water mixtures as a mobile phase. Standardisation was carried out using dilutions of the Supelco PAH mixture 610-M, which contains $16 \mathrm{PAH}$ included on the U.S. Environmental Protection Agency's priority pollutant list, namely: acenaphthene, acenaphthylene, anthracene, benz[a]anthracene, benzo[a]pyrene, benzo[b]fluoranthene, benzo[k]fluorathene, benzo[ghi]perylene, chrysene, dibenz $[a, h]$ anthracene, fluoranthene, fluorene, indeno[1,2,3cdpyrene, naphthalene, phenanthrene and pyrene (= PAH $\Sigma 16 \mathrm{C}$ ).

Tissue chemistry (trace metals). For trace metal analyses, aliquots of about $0.5 \mathrm{~g}$ of freeze dried tissue were digested at $120^{\circ} \mathrm{C}$ in a teflon bomb for $4 \mathrm{~h}$ with $5 \mathrm{~cm}^{3}$ concentrated $\mathrm{HNO}_{3}$. The resulting solution was made up to $50 \mathrm{~cm}^{3}$ with distilled water. Metal determinations were performed on an atomic absorption spectrophotometer (Perkin-Elmer model 372). Copper, iron, zinc and manganese were measured directly in an airacetylene flame; cadmium, lead, nickel, cobalt and chromium were measured using graphite furnace atomic absorption spectrophotometry, and mercury was reduced with $\mathrm{NaBH}_{4}$ and measured by flameless procedure. Deuterium background correction was used for $\mathrm{Cd}, \mathrm{Fe}, \mathrm{Pb}$ and $\mathrm{Zn}$.

Data analysis. To explore the relationship between neutral red retention time and the presence of the various contaminants, the data were tested by multi-stepwise linear regression. However, inasmuch as the literature is undecided as to whether their effects are additive or not, the organochlorines were tested both pooled (as $\mathrm{HCH}+$ Aroclor 1254 + DDT but excluding $\mathrm{PCB} \sum 8 \mathrm{C}$ as these $8 \mathrm{PCB}$ congeners are included in the formulation of Aroclor 1254) and individually.

\section{RESULTS}

\section{Organic contaminants}

The results of the organic contaminants analysis showed generally good agreement between sites for the 2 sampling periods, the notable exception being $\mathrm{HCH}$ which was appreciably higher in 1992 as compared to 1993. With the exception of $\mathrm{HCH}_{1}$ the highest levels of organic contaminants were found in tissues from Salute mussels, a site in the centre of the City of Venice considered to be high in contaminants derived from domestic waste. Organic contaminants were also high in mussel tissues from the industrial site in the Canale Vittorio Emanuele (CVE) as compared to the remaining sites (see Table 1 ).

\section{Metal contaminants}

Analysis of metal contaminants in tissues revealed greater variability than was observed for the organic contaminants between duplicate sites for the 2 sampling periods. Levels of $\mathrm{Cu}, \mathrm{Mn}, \mathrm{Pb}$ and $\mathrm{Co}$ were elevated during 1993, whereas $\mathrm{Fe}$ and $\mathrm{Hg}$ were lower as compared to 1992; the remaining metals were broadly unchanged between years. Also during 1993, metals in tissues from Adriatic mussels either doubled or remained unchanged as compared to levels in 1992 (Table 2).

Table 1. Contaminant body burdens of $\mathrm{HCH}$ isomers, DDT, PCBs (quantified as Aroclor 1254), PCB $28 \mathrm{C}$ (sum of 8 individual congeners), total chlorinated hydrocarbons (ng $\mathrm{g}^{-1} \mathrm{dry}$ wt), aliphatic hydrocarbons (UCM, unresolved complex mixtures, $\mu \mathrm{g} \mathrm{g}^{-1}$ dry wt), and PAH $\sum 16 \mathrm{C}$ (total of 16 polyaromatic hydrocarbons, $\mathrm{ng} \mathrm{g}^{-1}$ dry wt)

\begin{tabular}{|c|c|c|c|c|c|c|c|}
\hline Site & $\mathrm{HCH}$ & DDT & Aroclor 1254 & $\mathrm{PCB} \Sigma 8 \mathrm{C}$ & EOrganochlorines & UCM & PAH $\Sigma 16 C$ \\
\hline \multicolumn{8}{|l|}{1992} \\
\hline CVE & 18.62 & 34.00 & 854.36 & 448.89 & 906.98 & 441.09 & 336.89 \\
\hline Salute & 13.45 & 74.22 & 1383.61 & 745.50 & 1471.28 & 584.87 & 879.53 \\
\hline Crevan & 7.13 & 16.42 & 233.33 & 128.79 & 256.88 & 212.56 & 131.02 \\
\hline Adriatic & 5.52 & 10.74 & 107.85 & 53.83 & 124.11 & 322.92 & 112.95 \\
\hline \multicolumn{8}{|l|}{1993} \\
\hline CVE & 5.23 & 49.17 & 889.06 & 520.99 & 943.46 & 744.95 & 322.10 \\
\hline Salute & 3.60 & 65.49 & 1051.08 & 660.12 & 1120.17 & 774.11 & 828.06 \\
\hline Crevan & 1.37 & 19.90 & 169.41 & 100.85 & 190.67 & 236.00 & 137.85 \\
\hline L. Grande & 1.50 & 17.01 & 240.58 & 157.43 & 259.09 & 361.13 & 235.93 \\
\hline Alberoni & 2.98 & 22.38 & 217.53 & 145.28 & 242.89 & 207.23 & 210.67 \\
\hline Chroggia & 0.87 & 9.34 & 150.64 & 92.69 & 160.84 & 287.59 & 178.49 \\
\hline Adriatic & 3.54 & 12.97 & 112.39 & 65.35 & 128.89 & 230.70 & 85.72 \\
\hline
\end{tabular}


Table 2. Total body burdens of trace metals ( $\mathrm{gg} \mathrm{g}^{-1} \mathrm{dry} \mathrm{wt}$ ) in mussel tissues collected during 1992 and 1993

\begin{tabular}{|lrrrrrrrrrr}
\hline Site & $\mathrm{Cu}$ & \multicolumn{1}{c}{$\mathrm{Zn}$} & $\mathrm{Fe}$ & $\mathrm{Mn}$ & $\mathrm{Cr}$ & $\mathrm{Cd}$ & $\mathrm{Pb}$ & $\mathrm{Co}$ & $\mathrm{Ni}$ & $\mathrm{Hg}$ \\
\hline $\mathbf{1 9 9 2}$ & & & & & & & & & \\
CVE & 7.63 & 103.58 & 255.61 & 8.83 & 0.93 & 2.01 & 6.84 & 2.61 & 2.53 & 0.31 \\
Salute & 8.35 & 62.00 & 160.14 & 6.67 & 0.66 & 1.63 & 11.63 & 1.56 & 1.84 & 0.29 \\
Crevan & 7.67 & 62.37 & 414.71 & 13.49 & 1.14 & 1.77 & 4.34 & 1.33 & 3.30 & 0.58 \\
Adratic & 8.14 & 112.99 & 124.71 & 6.65 & 0.45 & 1.79 & 7.47 & 1.69 & 2.26 & 0.29 \\
1993 & & & & & & & & & \\
CVE & 13.41 & 97.16 & 230.26 & 18.09 & 8.56 & 2.68 & 59.30 & 5.89 & 14.41 & 0.14 \\
Salute & 28.50 & 110.49 & 189.69 & 19.39 & 1.64 & 0.86 & 16.98 & 3.64 & 5.22 & 0.28 \\
Crevan & 7.20 & 146.39 & 271.92 & 19.18 & 0.98 & 1.00 & 45.68 & 3.04 & 3.00 & 0.38 \\
L.Grande & 15.28 & 100.20 & 294.32 & 19.20 & 1.37 & 0.56 & 8.61 & 2.43 & 2.35 & 0.36 \\
Alberoni & 17.09 & 75.07 & 391.27 & 22.81 & 15.01 & 4.17 & 23.53 & 2.37 & 18.51 & 0.15 \\
Chioggia & 10.22 & 94.46 & 468.41 & 25.69 & 1.93 & 0.69 & 22.27 & 3.00 & 1.97 & 0.24 \\
Adriatic & 16.82 & 51.70 & 107.58 & 12.73 & 1.56 & 2.83 & 10.66 & 1.12 & 2.05 & 0.17 \\
\hline
\end{tabular}

\section{Neutral red retention}

The neutral red retention assay (Fig. 2) indicated that whilst blood cell lysosomes from the reference population in the Adriatic Sea had the capacity to retain the dye for $180 \mathrm{~min}$, those from the natural lagoon sites lost the dye to the cytosol between 0 and 33 min (range of mean values for all natural lagoon sites) and 120 and 138 min respectively after dye exposure for the 2 aquaculture sites at Chioggia and Alberoni. For the 4 sites sampled in both 1992 and 1993 (i.e. Adriatic, CVE, Salute and Crevan) there was good agreement for the neutral red retention times.

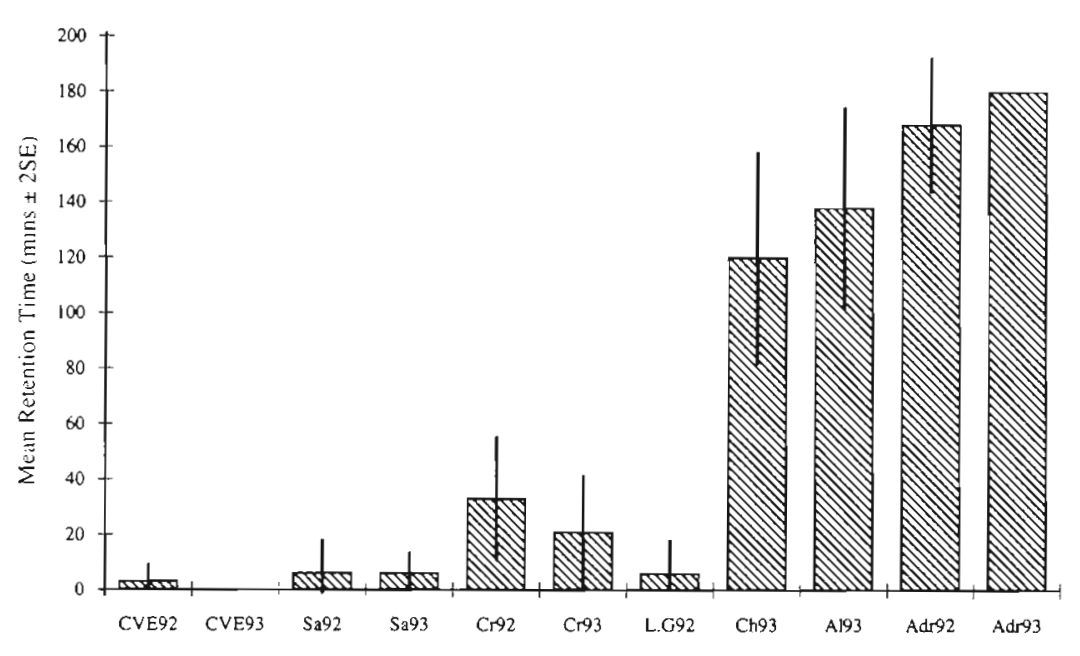

Fig. 2. Mean neutral red retention time $( \pm 2 \mathrm{SE})$ in blood cell lysosomes of mussels collected from sites in the Adriatic Sea and the Lagoon of Venice (Adr: Adriatic; Ch: Chioggia; Alb: Alberoni; LG: Lio Grande; Cr: Crevan; Sa: Salute; and CVE: Canale Vittorio Emanuele) during 1992 and 1993

\section{Statistical analysis}

The multi-stepwise regression analysis of all contaminant data using the pooled organochlorines (Tables 1 \& 2) produced a subset model of total organochlorines, mercury and cobalt which accounted for $83 \%$ of the biological variability. The $\mathrm{p}$ statistics for total organochlorines, cobalt and mercury were 0.010 0.023 and 0.006 respectively.

Regression analysis of individual organic contaminants indicated that whereas the 8 PCB congeners (PCB $\Sigma 8 C$ ), Aroclor 1254 and DDT could account for $43 \%(\mathrm{p}>0.03), 42 \%(\mathrm{p}<0.03)$ and $38 \%(\mathrm{p}<0.04)$ respectively of the biological variability, $\mathrm{HCH}$ could account for only $13 \%$ and was not significant. Neither PAH $\Sigma 16 C$ nor UCM produced a significant correlation with the times of neutral red retention.

\section{DISCUSSION}

The significant decrease in retention time exhibited by lysosomes of mussel blood cells from the industrial (CVE) and domestic waste (Salute) sites is consistent with the findings of previous studies using isolated digestive cells from contaminated animals (Lowe et al. 1992, 1995, Lowe \& Pipe 1994). Although there was a marked difference in the probe retention times among sites this was not reflected in the burdens of all contaminants. Both CVE and Salute were, for example, clearly more heavily contaminated with organochlorine and hydrocarbon compounds than the other sites; the patterns of distribution of the various metals among sites were less well defined. Even so, the multi-stepwise regression analysis highlighted mercury and cobalt as significant contributing factors 
to the observed changes in lysosomal structure and function.

In previous experiments, exposure to PAHs has been shown to reduce probe retention time in lysosomes (Lowe \& Pipe 1994, Lowe et al. 1995) and adversely effect lysosomal structure (Lowe et al. 1981). However, in the studies reported here the severity of the effect induced by the organochlorine compounds appears to 'mask' that induced by the PAH component. The regression analysis of the individual contaminants revealed that whilst PAHs could account for some $28 \%$ of the biological variability, the organochlorines with the exception of $\mathrm{HCH}$ accounted for between 38 and $43 \%$ of the variability.

The increased damage resulting from exposure to the organochlorines compared to that associated with PAHs in all probability reflects the fact that the former are bulkier. For example, DDT contains large chlorine atoms which contribute to membrane disruption (Nelson et al. 1990), in contrast to PAHs, which are generally more planar and produce less damage on penetrating cell membranes.

The argument for the effects of the organochlorines to be considered as additive may be found in the QSAR (Quantitative Structure Activity Relationship) literature. Broderius (1991) stated that 'if test chemicals conform to a QSAR that defines a suspected mode of toxic action, then one might expect that chemicals which define this mode will be strictly additive in their joint toxicity'. Whilst the analysis of the contribution of the organochlorine compounds to lysosomal damage in this investigation does not give any direct evidence as to whether their effect is additive, it does indicate that their mode of toxic action, with the exception of $\mathrm{HCH}$, is the same.

The smaller biological response associated with the $\mathrm{HCH}$ may be related to its structure, which is somewhat more planar than the other organochlorines, thereby exerting less of a damaging effect on the membranes. Alternatively, the lesser correlation may relate to the relative proportion of that contaminant compared to the other organochlorines. The tissue burden of the HCHs was approximately half that of DDT, which was an order of magnitude less than the $8 \mathrm{PCB}$ congeners and Aroclor 1254.

Of the trace metals studied, cobalt and mercury appeared to be most toxic, at least with regard to the biomarker measured. Supportive evidence for the inclusion of Co in the subset model may be found in Smith et al. (1984), who demonstrated that lysosomal membrane integrity was adversely effected following injection of rats with cobalt chloride, resulting in the release of acid hydrolases into the circulatory system. Similarly, with regard to mercury, Verity \& Brown (1968) demonstrated destabilization of lysosomal membranes in mice following exposure, whilst studies by Madsen \& Christensen (1978) indicated that mercury becomes localised within lysosomes in renal cells. Working with the colonial hydroid Campanularia flexuosa, Moore \& Stebbing (1976) demonstrated elevation of free lysosomal hydrolases following exposure to $\mathrm{Hg}$. which they attributed to decreased membrane stability resulting in reduced latency.

Whilst the studies cited above provide support for the hypothesis that cobalt and mercury contributed to the induction of biomarker responses in the mussels from polluted sites, it is unclear why other metals, notably $\mathrm{Fe}, \mathrm{Mn}, \mathrm{Cu}$ and $\mathrm{Ni}$, were not implicated, too. For example, Fe, $\mathrm{Mn}$ and $\mathrm{Co}$ are somewhat similar chemically and their ions are subject to handling by many common pathways (e.g. binding to, and transport by transferrins; Depledge et al. 1986, Goyer 1991). The answer may lie in some special toxicological characteristics of cobalt. For example, when administered to mammals, cobalt decreases levels of cytochrome P450 by inhibiting synthesis of the enzyme and decreasing its degradation (Timbrell 1991). Whether such effects occurred in mussels from the polluted sites and how they might influence the toxicity of organic pollutants awaits investigation.

With regard to copper, Cheng (1990) working with oyster Crassostrea virginica haemocytes showed that exposure to $\mathrm{Cu}$ inhibited release of lysosomal enzymes into the serum, whilst exposure to $\mathrm{Cd}$ was not inhibitory. By contrast, Viarengo et al. (1981) and Harrison \& Berger (1982), both working on mussel digestive cells, observed lysosomal membrane destabilization and associated enzyme leakage in response to $\mathrm{Cu}$ exposure. In the current study, copper was not implicated in toxicity, although recent studies by Pipe et al. (1995) have demonstrated that immunocompetence in mussels is adversely effected by this metal.

Very little is known concerning the intracellular distribution and binding of nickel (Goyer 1991). Binding to sulphydryl groups of metallothionein has been demonstrated in much the same way as mercury binding, but unlike mercury, nickel is nutritionally essential, so that the biochemical systems of the cell may be better able to detoxify and excrete excess nickel ions.

Depledge (1994) pointed out that whilst biomarkers which signify exposure to pollutants are useful, those which signify that organisms are experiencing adverse effects are more ecologically relevant. The significance of damage to the lysosomal vacuolar system, for an individual or a population, can be inferred from studies by Regoli (1992). Using depressed lysosomal latency in mussel digestive tissues as a biomarker of contaminant-induced damage, Regoli (1992) demonstrated that 4 mo depuration following metal contamination did not result in any increase in the latency 
period. As latency did not recover, damage to lysosomal membranes does not appear to be transient. Indeed, it may become more severe due to lipid peroxidation, a free radical chain reaction which causes further membrane damage (Mehlhorn 1986). In this context, studies by Moore \& Viarengo (1987) indicated that increased lysosomal membrane fragility in mussels is directly related to enhanced protein catabolism and consequently, failure of the membranes to recover in the short to medium term. This may have implications for impacted mussels in terms of reduced growth and reproductive potential.

Lowe et al. (1992) postulated that release of the neutral red dye into the cytosol following membrane damage may be due to impairment of the lysosomal membrane proton pump. The internal acid environment of lysosomes is maintained by a membrane $\mathrm{Mg}^{2+}$ ATPase dependent $\mathrm{H}^{+}$ion proton pump (Ohkuma et al. 1982). Dysfunction of the pump would lead to a marked increase of the intralysosomal $\mathrm{pH}$ and, in the absence of any gradient, free passage of the lysosomal contents including neutral red into the cytosol. Failure or dysfunction of the proton pump may be a direct consequence of contaminant action or alternatively the result of a reduction in ATP synthesis following contaminant damage to mitochondria; however, both of these points require further study.

In summary, the present study examined contaminant impact on mussels in the Lagoon of Venice using lysosomal neutral red retention as a biomarker of effects on blood cells. In addition, using correlative analysis, the relationship between the biomarker response (probe retention time) and total body burdens of a range of organic and inorganic contaminants was examined. Mussels from some parts of the study area were clearly impacted, as evidenced by impairment of lysosomal function in blood cells. The presence of organochlorines, cobalt and mercury appeared to be a major contributing factor to toxicity resulting in blood cell lysosomal pathology.

Acknowledgements. These investigations were funded by UNESCO as a component of the Venice Lagoon Ecosystem Study and by the Department of the Environment (Contract Number PECD 7/7/408).

\section{LITERATURE CITED}

Babich $\mathrm{H}$, Borenfreund $\mathrm{E}$ (1988) In vitro cytotoxicity of polychlorinated biphenyls (PCB) and toluenes to cultured bluegill sunfish BF-2 cells. In: Adams WJ, Chapman GA. Landis WG (eds) Aquatic toxicology and hazard assessment, Vol 10, ASTM STP 971 . American Society for Testing and Materials, Philadelphia, p 454-462

Ballschmiter K, Zell M (1980) Analysis of polychlorinated biphenyls (PCBs) by glass capillary chromatography.
Composition of technical Aroclor and Clophen PCB mixtures. $Z$ analyt Chem 302:20-31

Borenfreund E, Puerner JA (1985) Toxicity determined in vitro by morphological alterations and neutral red absorption. Toxicol Lett 24:119-124

Broderius SJ (1991) Modelling the joint toxicity of xenobiotıcs to aquatic organisms: basic concepts and approaches. In: Mayes MA, Baron MG (eds) Aquatic toxicology and risk assessment, Vol 14, ASTM STP 1124. American Society for Testing and Materials, Philadelphia, p 107-127

Bryan GW, Gibbs PE, Burt GR (1988) A comparison of the effectiveness of tri-n-butyltin chloride and five other organotin compounds in promoting the development of imposex in the dog whelk, Nucella lapillus. J mar biol Ass UK 68:733-734

Cheng TC (1990) Effects of in vivo exposure of Crassostrea virginica to heavy metals on haemocyte viability and activity levels of lysosomal enzymes. In: Perkins FO, Chang TC (eds) Pathology in marine science. Academic Press Inc, San Diego, p 513-524

Coles JA, Farley SR, Pipe RK (1994) Effects of fluoranthene on the immunocompetence of the common marine mussel, Mytilus edulis. Aquat Toxicol 30:367-379

Depledge $\mathrm{MH}$ (1994) The rational basis for the use of biomarkers as ecotoxicological tools. In: Fossi MC, Leonzio C, (eds) Nondestructive biomarkers in vertebrates. Lewis Publishers, Boca Raton, p 261-285

Depledge $\mathrm{MH}$, Chan R, Loh TT (1986) Iron distribution and transport in Scylla serrata (Forskảl). Asian mar Biol $3: 101-110$

Goyer RA (1991) Toxic effects of metals. In: Amdur MO, Doull $J$, Klaassen CD (eds) Casarett and Doull's toxicology, 4th edn. Pergamon Press, Oxford p 623-680

Haensly WE, Neff JM, Sharp JR, Morris AC, Bedgood MF Boem PD (1982) Histopathology of Pleuronectes platessa L. from Aber Wrac'h and Aber Benoit, Brittany, France long term effects of the Amoco Cadiz crude oil spill. J Fish Dis 5:365-391

Harrison FL, Berger R (1982) Effects of copper on latency of lysosomal hexosaminidase in the digestive cells of Mytilus edulis. Mar Biol 68:109-116

Kranz H, Peters N (1984) Melano-macrophage centres in liver and spleen of ruffe (Gymnocephalus cerna) from the Elbe Estuary. Helgoländer Meeresunters 37:415-424

Lowe DM, Moore MN, Clarke KR (1981) Effects of oil on digestive cells in mussels: quantitative alterations in cellular and lysosomal structure. Aquat Toxicol 1:213-226

Lowe DM, Moore MN, Evans BM (1992) Contaminant impact on interactions of molecular probes with lysosomes in living hepatocytes from dab Limanda Limanda. Mar Ecol Prog Ser 91:135-140

Lowe DM, Pipe RK (1994) Contaminant-induced lysosomal membrane damage in marine mussel digestive cells: an in vitro study. Aquat Toxicol 30:357-365

Lowe DM, Soverchia C, Moore MN (1995) Lysosomal membrane responses in the blood and digestive cells of mussels experimentally exposed to fluoranthene. Aquatic Toxicol 33: $105-112$

Madsen KM, Christensen EF (1978) Effects of mercury on lysosomal protein digestion in the kidney proximal tubule. Lab Invest 38:165-178

Mehlhorn RJ (1986) The interaction of inorganic species with biomembranes. In: Bernhard M, Brinkman FE, Sadler PJ (eds) The importance of chemical 'speciation' in environmental processes. Springer-Verlag, Heidelberg, p 85-97

Moore MN (1990) Lysosomal cytochemistry in marine environmental monitoring. Histochem J 22:189-191 
Moore MN (1992) Molecular cell pathology of pollutantinduced liver injury in flatfish: use of fluorescent probes. Mar Ecol Prog Ser 91:127-133

Moore MN Stebbing ARD (1976) The quantitative cytochemical effecs of three metal ions on a lysosomal hydrolase of a hydroid. J mar biol Ass UK 56:995-1005

Moore MN, Viarengo A (1987) Lysosomal membrane fragility and catabolism of cytosolic proteins: evidence for a relationship. Experientia 43:320-323

Nelson A, Auffret $N_{1}$ Borlakoglu J (1990) Interaction of hydrophobic organic compounds with mercury adsorbed dioleoylphosphatidylcholine monolayers. Biochim Biophys Acta 1021:205-216

Ohkuma S, Moriyama Y, Takano T (1982) Identification and characterisation of a proton pump on lysosomes by fluoroscein isothiocyanate-dextran fluorescence. Proc natl Acad Sci USA 79:2758-2762

Peek K, Gabbot PA (1989) Adipogranular cells from the manthe tissues of Mytilus edulis L. 1. Isolation, purification and biochemical characteristics of dispersed cells. J exp mar Biol Ecol 126:203-216

Pipe RK (1990) Differential binding of lectins to haemocytes of the mussel Mytilus edulis. Cell Tissue Res 261: $261-268$

Pipe RK (1993) The generation of reactive oxygen metabolites by the haemocytes of the mussel Mytilus edulis. Dev comp Immunol 16:111-122

This article was submitted to the editor
Pipe RK, Coles JA (1995) Environmental contaminants influencing immune function in marine bivalve molluscs. Fish Shellfish Immunol (in press)

Regoli F (1992) Lysosomal responses as a sensitive stress index in biomonitoring heavy metal pollution. Mar Ecol Prog Ser 84:63-69

Reinhardt SB, Van Vleet ES (1986) Lipid composition of twenty species of Antarctic midwater zooplankton and fish. Mar Biol 91:149-159

Smith RJ, Ignarro LJ, Fisher JW (1984) Lysosomal enzyme release: possible mechanisms of action of cobalt as an erythropoeitic stimulant. Proc Soc exp Biol Med 146:781-785

Timbrell JA (1991) Principles of biochemical toxicology, 2nd edn. Taylor \& Francis, London

Verity MA, Brown WJ (1968) Activation and stability of lysosomal acid phosphohydrolase. Biochem Biophys Acta 151:209-219

Viarengo A, Zanicchi $G$, Moore MN, Orunesu M (1981) Accumulation and detoxication of copper by the mussel Mytilus galloprovincialis Lam.: a study of the subcellular distribution in the digestive gland cells. Aquat Toxicol 1. $147-157$

Weeks BA, Anderson DP, DuFour A, Fairbother A, Goven A, Lahvis GP, Peters G (1992) In: Huggert RJ, Kimerle RA, Mehrle PM Jr, Bergman HL (eds) Immunological biomarkers to assess stress. Lewis Publishers, Chelsea, MI, p $211-234$

Manuscript first received: January 17, 1995

Revised version accepted: June 20, 1995 